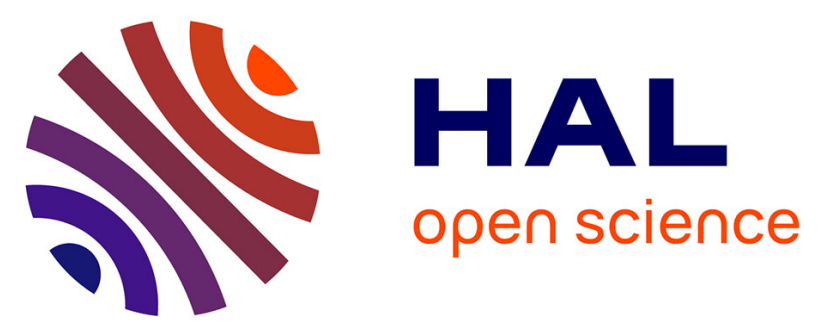

\title{
Glucosamine-6-phosphate Synthase from Escherichia coli: Mechanism of the Reaction at the Fructose 6-Phosphate Binding Site
}

\author{
Beatrice Golinelli-Pimpaneau, François Le Goffic, Bernard Badet
}

\section{To cite this version:}

Beatrice Golinelli-Pimpaneau, François Le Goffic, Bernard Badet. Glucosamine-6-phosphate Synthase from Escherichia coli: Mechanism of the Reaction at the Fructose 6-Phosphate Binding Site. Journal of the American Chemical Society, 1989, 111 (8), pp.3029-3034. 10.1021/ja00190a042 . hal-03280008

\section{HAL Id: hal-03280008 https://hal.science/hal-03280008}

Submitted on 6 Jul 2021

HAL is a multi-disciplinary open access archive for the deposit and dissemination of scientific research documents, whether they are published or not. The documents may come from teaching and research institutions in France or abroad, or from public or private research centers.
L'archive ouverte pluridisciplinaire HAL, est destinée au dépôt et à la diffusion de documents scientifiques de niveau recherche, publiés ou non, émanant des établissements d'enseignement et de recherche français ou étrangers, des laboratoires publics ou privés. 
evidence against the dipole-dipole attraction mechanism for mesophase formation; vide supra.) The nitro derivative (17b) has a much reduced $\mathrm{LC}$ range of only $25^{\circ} \mathrm{C}$, presumably associated with the buckling of the porphyrin ring caused by the bulky nitro group in the meso position. ${ }^{39}$

Finally, we wished to compare the mesomorphic properties of an ester of octaethanolporphyrin $\left(\mathrm{M}(\mathrm{EtOH})_{8} \mathrm{Por}\right)$ to that of an ester of (octaacetic acid) porphyrin, $\mathrm{M}(\mathrm{AcOH})_{8}$ Por. $^{25}$ The last two entries in Table I are isomers; they are the octa- $n$-hexanoate of $\mathrm{Zn}(\mathrm{EtOH})_{8}$ Por and the octa- $n$-hexyl ester of $\mathrm{Zn}(\mathrm{AcOH})_{8}$ Por, respectively. That is, they differ only in the directionality of the ester linkage. Quite surprisingly, their mesomorphic properties are completely different. The ester of $\mathrm{Zn}(\mathrm{EtOH})_{8}$ Por $(\mathbf{1 8 b})$ is not a liquid crystal at all, melting to an isotropic liquid at 169 ${ }^{\circ} \mathrm{C}$. The ester of $\mathrm{Zn}(\mathrm{AcOH})_{8}$ Por $(\mathbf{1 9 b})$ shows two broad LC phases extending over a range of $171^{\circ} \mathrm{C}$ before melting to an isotropic liquid at $232^{\circ} \mathrm{C} .{ }^{25}$ Clearly, there is still much art contained in the science of liquid crystals. ${ }^{40}$

Phase Behavior of Zinc Octakis ( $\beta$-(octyloxy)ethyl)porphyrin. $\mathrm{Zn}(\text { EtOOct })_{8}$ Por $(\mathbf{1 4 b})$ is a waxy solid at room temperature that crystallizes in long threads that are unsuitable for single-crystal $\mathrm{X}$-ray analysis. When crystals are placed between microscope cover slips and heated, one observes by microscopy between crossed polarizers a definite decrease in viscosity at the crystalline to liquid crystalline phase transition $\left(107^{\circ} \mathrm{C}\right)$. The compound becomes translucent, allowing observation of the optical texture (without requiring any shear or pressure). On further heating, there is some minor rearrangement of the compound and the cover slips but the LC does not begin to flow. The optical texture (Figure 4) resembles that of a columnar discotic phase. ${ }^{42}$ The disclinations are more curved than was the case with the octaesters, ${ }^{25}$ and the viscosity of the mesophase is substantially lower. If the temperature is held at $5-10^{\circ} \mathrm{C}$ below the clearing point (e.g., 155 ${ }^{\circ} \mathrm{C}$ ), the LC will flow slightly under the weight of the cover slips

(39) Bonnett, R.; Stevenson, G. F. J. Org. Chem. 1965, 30, 2791-2798.

(40) Although the reversal of ester functions is known to affect the transition temperatures of the rodlike liquid crystals, this effect is much less dramatic than that seen here. ${ }^{4 l}$ Furthermore, it is often attributed to a change in conjugation, ${ }^{41}$ which, clearly, does not apply to compounds $18 \mathrm{~b}$ and $19 \mathrm{~b}$.

(41) Gray, G. W. In ref 8, Vol. 2.

(42) (a) Guillon, D.; Weber, P.; Skoulios, A.; Piechocki, C.; Simon, J. Mol. Cryst. Liq. Cryst. 1985, 130, 223. (b) Guillon, D.; Skoulios, A.; Piechocki, C.; Simon, J.; Weber, P. Ibid. 1983, 100, 275. and wet the surface of the glass. Any sharp crystal protrusions will become rounded. Thus, although the LC phase is definitely not nematic, ${ }^{21,22,43}$ it does have enough conformational mobility at this temperature to seek a lower energy conformation, i.e., to self-order. This ordering process in the LC phase can be observed by changes in the absorption and emission spectra of the sample. ${ }^{36 a}$ If one repeats this procedure on a sample that appears amorphous (i.e., black) between crossed polarizers, the spectral shifts will be evident, although no order appears in the microscope. This implies that the spectral shifts are consequences of a short-range order that can appear under these conditions, although no longer range order, as seen in the microscope, is achieved. If heated to above the clearing point and then cooled slowly, the porphyrin will form a polycrystalline array on the surface.

These materials can be easily capillary-filled into thin cells between conducting substrates, resulting in large-area devices with unusual photoelectrical properties. ${ }^{36 \mathrm{~b}}$ Figure 4 shows the optical textures of such a cell (ca. $2.5 \mu \mathrm{m}$ thick) in both the solid and the liquid crystalline phases. It is also possible to spin-coat these porphyrins onto a support and monitor their photophysical properties as a function of increasing order. ${ }^{36 a}$

\section{Conclusion}

An efficient synthesis has been described for a new series of liquid crystalline porphyrins based on the hitherto unreported octaethanolporphyrin. The thermotropic behavior of these compounds has been investigated as a function of the length of the ether side chains and of the central metal. The LC phase is fluid enough to permit some short-range ordering of the material, and the isotropic phase permits capillary-filling and longer range ordering.

Acknowledgment. We are grateful to the National Science Foundation for support of the Materials Research Group at the University of Texas under whose aegis this work was performed. We are also grateful to Professor Donald Paul and Dr. Pamela $\mathrm{S}$. Tucker for use of the differential scanning calorimeter.

(43) We have not yet identified the type of discotic mesophase formed. The standard miscibility tests for LC phase identification are rendered problematic by (a) the lack of commercially available discotic LCs and (b) the fact that discotic liquid crystals of the same phase are known to be immiscible if they are of substantially different molecular sizes. ${ }^{21}$

\title{
Glucosamine-6-phosphate Synthase from Escherichia coli: Mechanism of the Reaction at the Fructose 6-Phosphate Binding Site
}

\author{
Béatrice Golinelli-Pimpaneau, François Le Goffic, and Bernard Badet* \\ Contribution from the Laboratoire de Bioorganique et Biotechnologies, ENSCP, 11, rue Pierre et \\ Marie Curie, 75231 Paris Cédex 05, France. Received May 26, 1988
}

\begin{abstract}
A mechanistic study on the pure glucosamine-6-phosphate synthase from Escherichia coli has been undertaken. The stereochemistry of the reaction and the existence of a small intramolecular hydrogen transfer allow us to propose a mechanism consistent with its classification in the $2 R$ aldose/ketose isomerase class. The fate of solvent tritium in substrate and product shows that proton transfer is followed by a slower step and that formation of a fructosimine 6-phosphate intermediate is rate limiting.
\end{abstract}

The first step in amino sugar metabolism is the interconversion of fructose 6-phosphate and glucosamine 6-phosphate catalyzed by glucosamine-6-phosphate isomerase ${ }^{1}$ (glucosamine-6P deaminase, EC 5.3.1.10) and by L-glutamine:D-fructose-6-phosphate

(1) Comb, D. G.; Roseman, S. Methods Enzymol. 1962, 5, 422-426. amidotransferase ${ }^{2}$ (glucosamine-6P synthase, EC 2.6.1.16). The $n a g B$ - (deaminase) and $g / m S$ - (synthase) encoded proteins, mapping respectively at minutes 15 and 84 on Escherichia coli chromosome, ${ }^{3}$ are able to synthesize glucosamine- $6 \mathrm{P}$, but only the

(2) Ghosh, S.; Blumenthal, H. J.; Davidson, E.; Roseman, S. J. Biol. Chem. $1960,235,1265-1273$. 
deaminase-catalyzed reaction seems to work reversibly. The lethal effect of mutations in the $E$. coli glmS gene ${ }^{4}$ suggests that glucosamine-6P deaminase cannot be considered as an alternative route, at least in $E$. coli, for the biosynthesis of amino sugars although its molecular activity in this direction is some 20 -fold higher than the activity of the synthase. ${ }^{5}$

The two enzymes belong to both ketose/aldose isomerase and amidotransferase groups. The stereochemistry of $E$. coli glucosamine-6P deaminase reaction (ammonia dependent) had been investigated about 1 decade ago, ${ }^{6}$ and a low amount of intramolecular tritium transfer $(0.6 \%)$ during the formation of fructose-6P was demonstrated. These properties were interpreted by a mechanism similar to that established by Rose for other isomerases. ${ }^{7,8}$ The recent purification to homogeneity 9,10 of the synthase (glutamine dependent) from $E$. coli prompted us to investigate the stereochemistry of the catalyzed reaction. The results described below are interpreted in terms of a base-catalyzed carbonyl enolization mechanism involving fructosimine- $6 \mathrm{P}$ as an intermediate. Imine formation and glucosamine- $6 \mathrm{P}$ release represent the two steps of highest energy of the reaction, the partition ratio of solvent tritium reflecting in our case the relative heights of the two barriers; the formation of fructosimine- $6 \mathrm{P}$ requires 1.9 $\mathrm{kcal} / \mathrm{mol}$ more than product release.

\section{Experimental Section}

Materials. Phosphoglucose isomerase (EC 5.3.1.9) from bakers' yeast (510 units $/ \mathrm{mg}$ in $2.6 \mathrm{M}$ ammonium sulfate), fructose-6-phosphate kinase (EC 2.7.1.11) from rabbit muscle (210 units/mg in $1.4 \mathrm{M}$ ammonium sulfate), and phosphomannose isomerase (EC 5.3.1.8) from bakers' yeast (95 units $/ \mathrm{mg}$ in $3.2 \mathrm{M}$ ammonium sulfate) were from Sigma. Acid phosphatase (EC 3.1.3.2) from potato (6 units/mg in $3.2 \mathrm{M}$ ammonium sulfate) and hexokinase from yeast ( 140 units $/ \mathrm{mg}$ in $3.2 \mathrm{M}$ ammonium sulfate) were from Boehringer-Mannheim. Glucosamine-6P synthase was purified as described. ${ }^{9}$

All chemicals were of the highest quality commercially available. The radiolabeled compounds were purchased from CEA.

$E$. coli Glucosamine-6P Deaminase Purification. During the purification, the enzyme activity was assayed at $37{ }^{\circ} \mathrm{C}$ for fructose- $6 \mathrm{P}$ formation as described. ${ }^{11}$

E. coli $3000 \mathrm{Hfr}$ (ATCC 25257) was grown on glucosamine as the sole carbon source in a minimal salt medium. ${ }^{11}$ The purification procedure was modified as follows. After disruption of the cells $(40 \mathrm{~g})$ with alumina $(70 \mathrm{~g}$ ) and resuspension in $20 \mathrm{mM}$ Mes buffer, $\mathrm{pH} 5.7$, the supernatant $(140 \mathrm{~mL})$ was treated with a $2 \%$ solution of protamine sulfate $(40 \mathrm{~mL})$ at the same $\mathrm{pH}$. After centrifugation $(44000 \mathrm{~g}, 10 \mathrm{~min})$, the supernatant (adjusted to pH 5.4 with $1 \mathrm{M}$ acetic acid) was loaded at $80 \mathrm{~mL} / \mathrm{h}$ on a Q-Sepharose fast-flow column $(2.6 \times 19 \mathrm{~cm})$ preequilibrated in $20 \mathrm{mM}$ Mes buffer-1 mM dithiothreitol, $\mathrm{pH} 5.4$ (buffer A). The column was washed with $100 \mathrm{~mL}$ of starting buffer and eluted by a $1000-\mathrm{mL}$ linear gradient of $0-0.5 \mathrm{M} \mathrm{NaCl}$ in buffer $\mathrm{A}$. Active fractions $(30 \mathrm{~mL})$ ap. pearing at $0.15 \mathrm{M} \mathrm{NaCl}$ were pooled, concentrated to $9 \mathrm{~mL}$ by ultrafiltration (Amicon, PM-10 membrane), and dialyzed against $20 \mathrm{mM}$ Tris- $\mathrm{HCl}, \mathrm{pH} 8$ (buffer $\mathrm{B}$ ). The solution was then loaded at $4 \mathrm{~mL} / \mathrm{min}$ on a Mono-Q HR 10/10 FPLC column, and elution was performed by a $100-\mathrm{mL}$ linear gradient of $0-0.25 \mathrm{M} \mathrm{NaCl}$ in buffer $\mathrm{B}$.

The specific activity of the enzyme, which displayed a single band on sodium dodecyl sulfate-polyacrylamide gel electrophoresis $\left(M_{\mathrm{r}}=30000\right.$ \pm 1000 ) was 415 units $/ \mathrm{mg}$. The enzyme was stored at $-20^{\circ} \mathrm{C}$ in $60 \mathrm{mM}$ $\mathrm{KPO}_{4}, 1 \mathrm{mM}$ EDTA, $5 \mathrm{mM}$ dithiothreitol, and $20 \%$ glycerol $\mathrm{pH} 7$

Colorimetric Assays. Glucosamine-6P was quantified by the Morgan-Elson procedure ${ }^{9}$ using glucosamine- $6 \mathrm{P}$ as a standard.

Fructose, fructose- $6 \mathrm{P}$, and fructose- $1,6 \mathrm{P}_{2}$ were quantified with the anthrone reagent ${ }^{12}$ modified as follows: $100 \mu \mathrm{L}$ of concentrated $\mathrm{HCl}, 100$ $\mu \mathrm{L}$ of $90 \% \mathrm{HCOOH}$, and $750 \mu \mathrm{L}$ of freshly prepared anthrone reagent (20 mg in $100 \mathrm{~mL}$ of $80 \%$ sulfuric acid) were added to $100 \mu \mathrm{L}$ of the

(3) Bachmann, B. J. Microbiol. Rev. 1983, 47, 180-230

(4) Sarvas, M. J. Bacteriol. 1971, 105, 467-471.

(5) Calcagno, M.; Campos, P. J.; Mulliert, G.; Suastegui, J. Biochim

Biophys. Acta 1984, 787, 165-173.

(6) Midelfort, C. F.; Rose, I. A. Biochemistry 1977, 16, 1590-1596.

(7) Rieder, S. V.; Rose, I. A. J. Biol. Chem. 1959, 234, 1007-1010.

(8) Rose, I. A. Brookhaven Symp. Biol. 1962, 15, 293-309.

(9) Badet, B.: Vermoote, P.; Haumont, P. Y.: Lederer, F.; Le Goffic, F. Biochemistry 1987, 26, 1940-1948.

(10) Dutka-Malen, S.; Mazodier, P.; Badet, B. Biochimie 1988, 70 , $287-290$

(11) Comb, D. G.; Roseman, S. J. Biol. Chem. 1958, 232, 807-827.

(12) Jermyn, M. A. Anal. Biochem. 1975, 68, 332-335. sample containing the sugar. The mixture was heated at $100^{\circ} \mathrm{C}$ for 3 $\mathrm{min}$ and then cooled in ice for $10 \mathrm{~min}$. After $15 \mathrm{~min}$ of ultrasonic vibrations, the optical density at $630 \mathrm{~nm}$ was measured.

Synthesis of $(1 R)-\left[1-{ }^{3} \mathrm{H}\right]$ Fructose-6P. Except when indicated, $(1 R)-\left[1-{ }^{3} \mathrm{H}\right]$ fructose-6P was obtained from the incubation of glucose-6P with glucosephosphate isomerase in tritiated water. Glucosephosphate isomerase and fructose-6P kinase were dialyzed against $70 \mathrm{mM}$ Tris- $\mathrm{HCl}$, pH 8

The reaction mixture containing $150 \mathrm{mM}$ Tris- $\mathrm{HCl}, \mathrm{pH} 8,1.5 \mathrm{mM}$ $\mathrm{MgCl}_{2}, 30 \mathrm{mM}$ glucose-6P, 1.2 equiv of ATP, and glucosephosphate isomerase $(25$ units $/ \mathrm{mL})$ in tritiated water $(40 \mathrm{mCi} / \mathrm{mL})$ at $25^{\circ} \mathrm{C}$ was treated after $1 \mathrm{~h}$ with fructose-6P kinase ( 40 units $/ \mathrm{mL})$. After $3 \mathrm{~h}$ the incubation mixture was diluted (4-fold) and $(1 R)-\left[1-{ }^{3} \mathrm{H}\right]$ fructose-1, $6 \mathrm{P}_{2}$ was purified as described below. The purified sugar $(180 \mu \mathrm{M})$ was then incubated with phosphatase $(0.1 \mathrm{unit} / \mathrm{mL})$ in $3 \mathrm{mM}$ magnesium acetate, $\mathrm{pH}$ 5. After overnight incubation at room temperature, the $\mathrm{pH}$ was raised to 6 and $(1 R)-\left[1-{ }^{3} \mathrm{H}\right]$ fructose was isolated as described below. The purified sugar (2.3 mM) in $40 \mathrm{mM}$ Hepes buffer, $\mathrm{pH} 7.5,36 \mathrm{mM} \mathrm{MgCl}$, and $18 \mathrm{mM}$ ATP was incubated at $30^{\circ} \mathrm{C}$ for $2 \mathrm{~h}$ in the presence of hexokinase ( 3 units $/ \mathrm{mL}) .(1 R)-\left[1-{ }^{3} \mathrm{H}\right]$ Fructose-6P was then purified as described below.

For the synthesis of $(1 S)-\left[1-{ }^{3} \mathrm{H}\right]$ fructose- $6 \mathrm{P}$, the same procedure was used with the following modifications: $\left[1-{ }^{3} \mathrm{H}\right]$ glucose $(32 \mu \mathrm{mol}, 10 \mu \mathrm{Ci})$ was incubated at $30^{\circ} \mathrm{C}$ for $4 \mathrm{~h}$ in $2 \mathrm{~mL}$ of $40 \mathrm{mM}$ Hepes buffer, $\mathrm{pH} 7.5$, $8 \mathrm{mM} \mathrm{MgCl}_{2}$, and $72 \mu \mathrm{mol}$ of ATP in the presence of hexokinase (14 units), glucosephosphate isomerase ( 7 units), and fructose-6P kinase (22 units).

Synthesis of $(1 R)-\left[1-{ }^{3} \mathrm{H}\right]$ Fructose-6P Used for the Intramolecular Tritium Transfer Experiment. The procedure is similar to that described above except tritiated water of higher specific radioactivity $(800 \mathrm{mCi} /$ $\mathrm{mL}$ ) was used. The solution containing $(1 R)-\left[1-{ }^{3} \mathrm{H}\right]$ fructose- $1,6 \mathrm{P}_{2}$ was lyophilized and the sample kept at $-80^{\circ} \mathrm{C}$ in $95 \%$ ethanol. Before use, the solution was filtered $(0.22 \mu \mathrm{m})$, evaporated to dryness, and redissolved in the appropriate buffer for purification.

Synthesis of $\left[2-{ }^{3} \mathbf{H}\right]$ Glucosamine-6P. A solution of $20 \mathrm{mM}$ fructose $-6 \mathrm{P}$ in $0.5 \mathrm{~mL}$ of $100 \mathrm{mM}$ Tris- $\mathrm{HCl}-200 \mathrm{mM} \mathrm{NH}_{4} \mathrm{Cl}, \mathrm{pH} 7.8$, was incubated overnight at room temperature with purified glucosamine-6P deaminase (2.4 units). Fructose-6P and glucosamine-6P were then separated as described below.

Purification of Radiolabeled Sugars. Fructose- $6 \mathrm{P}$ and fructose- $1,6 \mathrm{P}_{2}$ were separated on a Mono-Q HR 10/10 FPLC column (Pharmacia). The column, loaded at $2 \mathrm{~mL} / \mathrm{min}$ was washed at $1 \mathrm{~mL} / \mathrm{min}$ with $20 \mathrm{mM}$ triethylammonium bicarbonate (TEAB), $\mathrm{pH} 8.2$, and eluted with a 60 min linear gradient of $20 \mathrm{mM}$ to $1 \mathrm{M}$ TEAB. The sugar-containing fractions were pooled, evaporated to dryness, redissolved in a $1 / 1$ water-2-propanol mixture, and evaporated again; this operation was repeated several times.

Fructose was purified by filtration through a AG2-X8 (Bio-Rad, acetate form) column eluted with water.

Fructose-6P and glucosamine-6P were separated on a Mono-Q HR $5 / 5$ FPLC column (Pharmacia). After loading, the column was washed for $5 \mathrm{~min}$ at $1 \mathrm{~mL} / \mathrm{min}$ with the starting buffer and then eluted at 0.5 $\mathrm{mL} / \mathrm{min}$ with a $30-\mathrm{min}$ linear gradient of $20-500 \mathrm{mM} \mathrm{TEAB}, \mathrm{pH} 8.2$. The samples were evaporated, redissolved in a $1 / 1$ water-2-propanol mixture, and evaporated to dryness. The operation was repeated several times.

Intramolecular Tritium Transfer. Glucosamine-6P synthase ( 5 units) was incubated at $37^{\circ} \mathrm{C}$ in $5 \mathrm{~mL}$ of $100 \mathrm{mM}$ Hepes buffer, $\mathrm{pH} 7.4$, containing $\left[{ }^{3} \mathrm{H}\right]$ fructose- $6 \mathrm{P}(273120 \mathrm{cpm} / \mu \mathrm{mol} ; 82.6 \mu \mathrm{mol})$ and $\mathrm{L}-$ glutamine $(100 \mu \mathrm{mol})$. Aliquots of $1-\mathrm{mL}$ were removed at $0 \mathrm{~min}, 15 \mathrm{~min}$, $1 \mathrm{~h}, 4 \mathrm{~h}$, and $21 \mathrm{~h}$ and acidified to $\mathrm{pH} 2$ with $2 \mathrm{~N} \mathrm{HCl}(150 \mu \mathrm{L})$. After the $\mathrm{pH}$ was raised to $7-8$ with $10 \mathrm{~N} \mathrm{NaOH}(10-15 \mu \mathrm{L})$, fructose-6P and glucosamine-6P were quantified by the anthrone and Morgan-Elson procedures. Water was lyophilized in a closed system, and both sugars were purified by FPLC as described above.

Quenching Conditions. After quenching to $\mathrm{pH} 2$, the residual glucosamine-6P synthase activity was estimated to be $0.5 \%$ of the initial activity.

\section{Results}

Stereospecificity of Hydrogen Exchange. $(1 R)-\left[1-{ }^{3} \mathrm{H}\right]-$ or $(1 S)-\left[1-{ }^{3} \mathrm{H}\right]$ fructose-6P which had been prepared with bakers' yeast glucosephosphate isomerase, an enzyme of known stereospecificity, ${ }^{13,14}$ was allowed to react with the bacterial glucosamine-6P synthase. The enzyme catalyzes an efficient tritium

(13) Topper, Y. J. J. Biol. Chem. 1957, 225, 419-425

(14) Rose, I. A.; O'Connell, E. L. Biochim. Biophys. Acta 1960, 42, $159-160$. 
Table I. Hydrogen Exchange: Requirements and Stereospecificity

\begin{tabular}{|c|c|c|c|c|}
\hline \multirow{2}{*}{$\begin{array}{l}\text { enzyme } \\
\text { (units) }^{a}\end{array}$} & \multirow{2}{*}{$\begin{array}{l}\text { gluta- } \\
\text { mine }\end{array}$} & \multirow{2}{*}{$\begin{array}{c}{\left[1-{ }^{3} \mathrm{H}\right]-} \\
\text { fructose- } 6 \mathrm{P}\end{array}$} & \multicolumn{2}{|c|}{$\begin{array}{l}\text { cpm liberated into } \\
\text { water (\% of total } \\
\text { counts) }\end{array}$} \\
\hline & & & $30 \mathrm{~min}$ & $4 \mathrm{~h}$ \\
\hline \multicolumn{5}{|c|}{ Part $\mathrm{A}^{b}$} \\
\hline & + & & 110 & $120(0.3)$ \\
\hline PGI (1 unit) & - & $1 S$ & 170 & $270(0.6)$ \\
\hline GlmS (0.1 unit) & - & $1 S$ & 120 & $120(0.3)$ \\
\hline GlmS (0.1 unit) & + & is & 170 & $280(0.7)$ \\
\hline \multicolumn{5}{|c|}{ Part $B^{b}$} \\
\hline & + & $1 R$ & & $25(0.06)$ \\
\hline PGI (1 unit) & - & 11 & 24300 & $30500(72)$ \\
\hline GlmS $(0.1$ unit $)$ & - & $1 R$ & & $75(0.2)$ \\
\hline GlmS (0.1 unit) & + & $1 R$ & 8400 & $20200(48)$ \\
\hline \multicolumn{5}{|c|}{ Part $C^{c}$} \\
\hline & + & $1 R$ & & $45(0.4)$ \\
\hline PGI (1 unit) & - & $1 R$ & & $8190(82)$ \\
\hline $\mathrm{GImS}$ (2.3 unit) & + & $1 R$ & & $9460(95)$ \\
\hline \multicolumn{5}{|c|}{$\begin{array}{l}{ }^{a} \text { PGI: glucose-6P isomerase; GlmS: glucosamine- } 6 \mathrm{P} \text { synthase } \\
\text { Reaction mixtures }(0.5 \mathrm{~mL}) \text { containing } 100 \mathrm{mM} \text { Hepes, } \mathrm{pH} 7.3,1.7 \\
\mathrm{mM}\left[{ }^{3} \mathrm{H}\right] \mathrm{Fru}-6 \mathrm{P}(50000 \mathrm{cpm} / \mu \mathrm{mol}) \text {, and } 6 \mathrm{mM} \text { L-glutamine when } \\
\text { indicated were incubated at } 25{ }^{\circ} \mathrm{C} \text {. The reaction was stopped by } \\
\text { freezing in liquid nitrogen, and water was lyophilized in a closed vessel } \\
\text { As in footnote } b \text { except } 2 \mathrm{mM}\left[{ }^{3} \mathrm{H}\right] \mathrm{Fru}-6 \mathrm{P}(10000 \mathrm{cpm} / \mu \mathrm{mol} \text {; ob } \\
\text { tained from the deaminase-catalyzed reaction in tritiated water; see } \\
\left.\text { Synthesis of }\left[2-{ }^{3} \mathrm{H}\right] \text { glucosamine- } 6 \mathrm{P}\right) \text { was used. }\end{array}$} \\
\hline
\end{tabular}

Table II. Position of Solvent Tritium in Substrate and Product ${ }^{a}$

$$
\text { Fru-6P } \underset{\mathrm{G} \operatorname{lmS}}{\stackrel{{ }^{3} \mathrm{H}_{2} \mathrm{O} / \mathrm{Gln}}{\longrightarrow}}\left[1-{ }^{3} \mathrm{H}\right] \mathrm{Fru}-6 \mathrm{P}+\left[{ }_{\text {II }}^{3} \mathrm{H}\right] \mathrm{GlcNH}_{2}-6 \mathrm{P}
$$

\begin{tabular}{lcc}
\hline & $\begin{array}{c}\text { cpm in solvent protons } \\
\text { (\% of total counts) }\end{array}$ \\
\hline part $\mathrm{A}^{b}$ & $\stackrel{\mathrm{I} \stackrel{\mathrm{PGI}}{\rightleftharpoons} \text { Glc-6P }}{8920(89)}$ \\
part B & $\mathrm{II} \stackrel{\text { deaminase }}{\rightleftharpoons}$ Fru-6P $+\mathrm{NH}_{4}{ }^{+}$ & $10020(100)$
\end{tabular}

${ }^{a}$ Glucosamine-6P synthase (GlmS, 0.46 unit) was incubated at 37 ${ }^{\circ} \mathrm{C}$ in tritiated water $(1 \mathrm{~mL}, 40 \mathrm{mCi})$ containing $20 \mathrm{mM}$ Fru-6P, 20 $\mathrm{mM}$ glutamine (Gln), and $50 \mathrm{mM}$ Hepes, $\mathrm{pH} 7.3$. The reaction was stopped at $62 \%$ conversion $(90 \mathrm{~min}) ; \mathrm{Fru}-6 \mathrm{P}$ and $\mathrm{GlcNH}_{2}-6 \mathrm{P}$ were purified on a Mono-Q FPLC column as described under Experimental Section. ${ }^{b}\left[1-{ }^{3} \mathrm{H}\right]$ Fru-6P $(1.5 \mu \mathrm{mol}, 10000 \mathrm{cpm})$ in $1 \mathrm{~mL}$ of $50 \mathrm{mM}$ Hepes, $\mathrm{pH} 7.3$, was incubated with glucose-6P isomerase (PGI, 7 units) at $25^{\circ} \mathrm{C}$ for $5 \mathrm{~h}$. The mixture was frozen in liquid nitrogen, and water was lyophilized in a closed vessel. ${ }^{c}\left[{ }^{3} \mathrm{H}\right] \mathrm{GlcNH}_{2}-6 \mathrm{P}(10000$ $\mathrm{cpm}$ ) diluted to $1.1 \mu \mathrm{mol}$ with unlabeled material was incubated at 25 ${ }^{\circ} \mathrm{C}$ in $1 \mathrm{~mL}$ of $100 \mathrm{mM}$ Hepes, $\mathrm{pH} 7.3$, with deaminase (2.4 units). After $5 \mathrm{~h}$, water was lyophilized in a closed vessel and counted.

exchange only between the $1 R$ stereoisomer and water. As shown in Table $\mathrm{I}$, this exchange requires the addition of L-glutamine, demonstrating that the enzyme does not enolize fructose-6P before the addition of glutamine.

In a complementary experiment fructose-6P and glutamine were incubated in tritiated water, and the positions of the label in substrate and in product were determined. As indicated in Table II approximately $90 \%$ of the label initially present in the isolated fructose-6P was reexchanged into water by incubation with the pro- $R$-hydrogen-specific glucosephosphate isomerase. On the other hand, the isolated glucosamine-6P was treated with homogeneous glucosamine-6P deaminase which catalyzes the reversible conversion of glucosamine- $6 \mathrm{P}$ into fructose- $6 \mathrm{P}$ and ammonia with complete equilibration of the amino sugar $\mathrm{C}_{2}$ hydrogen with the solvent: ${ }^{6} 100 \%$ of the counts initially present in glucosamine- $6 \mathrm{P}$ were liberated into water, thus proving that the product of the synthase-catalyzed reaction was stereospecifically tritiated at $C_{2}$.

Reversibility of the Reaction. As previously reported, ${ }^{2,9}$ using large amounts of enzyme ( 1 unit), the reversibility of the reaction could not be detected by the glucosephosphate isomerase/glucosephosphate dehydrogenase coupled assay in the presence of 10 $\mathrm{mM}$ each of the products. However the incubation of $\left[2-{ }^{3} \mathrm{H}\right]-$ glucosamine-6P (10 mM, under the conditions used in the ex-
Table III. Enzymatic Analysis of the Diastereomeric Purity of $\left[1-{ }^{3} \mathrm{H}\right]$ Fructose-6P Used in Intramolecular Transfer Experiment ${ }^{a}$

\begin{tabular}{ccc} 
& \multicolumn{2}{c}{$\begin{array}{c}\text { radioactivity released into } \\
\text { water }\end{array}$} \\
\cline { 2 - 3 } added & \multicolumn{3}{c}{$\begin{array}{c}\text { \% of total } \\
\text { counts }\end{array}$} \\
\hline enzyme & $\mathrm{cpm}$ & 0.5 \\
none & 128 & 90 \\
PGI & 24320 & 8.3 \\
\hline
\end{tabular}

${ }^{a}$ Radiolabeled fructose-6P (27000 cpm), synthesized as described under Experimental Section, was incubated in $1 \mathrm{~mL}$ of $50 \mathrm{mM}$ Hepes, $\mathrm{pH} 7.3-15 \mathrm{mM}$ Fru-6P at $30^{\circ} \mathrm{C}$ for $5 \mathrm{~h}$ with glucose- $6 \mathrm{P}$ isomerase (PGI, 7 units) or mannose-6P isomerase (PMI, 7 units) as indicated. The radioactivity released into water was determined following lyophilization in a closed vessel.

Table IV. Intramolecular Tritium Transfer ${ }^{a}$

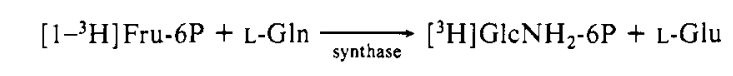

\begin{tabular}{|c|c|c|c|c|c|c|}
\hline \multirow{3}{*}{$\begin{array}{c}\text { fractional } \\
\text { extent } \\
\text { of reaction }(\%)\end{array}$} & \multirow{3}{*}{$\begin{array}{l}\text { fraction of } \\
\text { counts released } \\
\text { in water }\end{array}$} & \multicolumn{3}{|c|}{$\begin{array}{l}\text { sp. radioact. } \\
(\mathrm{cpm} / \mu \mathrm{mol})^{b}\end{array}$} & \multicolumn{2}{|c|}{ ratio } \\
\hline & & \multirow{2}{*}{$\begin{array}{c}\text { Fru-6P, } \\
B_{\text {exp }} \\
\end{array}$} & \multicolumn{2}{|c|}{$\mathrm{GlcNH}_{2}-6 \mathrm{P}$} & \multirow{2}{*}{$\begin{array}{l}\overline{C_{\text {exp }} /} \\
B_{0, \exp }\end{array}$} & \multirow{2}{*}{$\begin{array}{l}C / \\
B_{0}\end{array}$} \\
\hline & & & $C_{\exp }$ & $C$ & & \\
\hline 31.3 & 30 & 287900 & 31230 & 3920 & 11.4 & 1.6 \\
\hline 48. & 78 & 204 & 28 & 1410 & 10.5 & 0.6 \\
\hline 76 & 80.8 & 191510 & 31230 & 3920 & 11.4 & 1.6 \\
\hline 80.4 & 85.7 & & 28920 & 1610 & 10.6 & 0.6 \\
\hline 100 & & 121200 & 28210 & 900 & 10.3 & 0.4 \\
\hline
\end{tabular}

${ }^{a}$ The experiment was run with the $\left[1-{ }^{3} \mathrm{H}\right] \mathrm{Fru}-6 \mathrm{P}$ analyzed in Table III under the conditions described under Experimental Section. ${ }^{b}$ The specific radioactivities (cpm/ $\mu \mathrm{mol})$ used are as follows: initial Fru- $6 \mathrm{P}$, $B_{0, \exp }=273120 ; 1 R-1-{ }^{3} \mathrm{H}$, initial $(1 R)-\left[1-{ }^{3} \mathrm{H}\right]$ Fru-6P $B_{0}=[1-(a+$ b) $] B_{0, \exp }$; isolated Fru-6P, $B_{\text {exp }}$; isolated $(1 R)-\left[1-{ }^{3} \mathrm{H}\right]$ Fru-6P, $B=B_{\text {exp }}-$ $(a+b) B_{0, \exp } ;$ isolated GlcNH ${ }_{2}-6 \mathrm{P}, C_{\text {exp }}$; isolated $\left[2 \cdot{ }^{3} \mathrm{H}\right] \mathrm{GlcNH} \mathrm{CH}_{2}-6 \mathrm{P}, C$ $=C_{\text {exp }}-(a+b) B_{0, \exp }$. All calculations were made with $a+b=0.1$.

periment described in Table IIB) with the synthase ( 2.3 units) resulted in a small release of tritium $(1-2 \%)$ into the medium which was independent of the presence of glutamate (added to $10 \mathrm{mM}$ ).

Tritium Transfer. To examine the possibility of intramolecular proton transfer in the glucosamine-6P synthase case, $(1 R)$ - $[1$ $\left.{ }^{3} \mathrm{H}\right]$ fructose-6P of high specific radioactivity was prepared by incubation of glucose-6P in tritiated water with excess glucosephosphate isomerase as described under Experimental Section. The tritiated fructose-6P however turned out to be contaminated by $8 \%$ of $1 S$ isomer as determined by use of mannosephosphate isomerase (Table III). This stereospecifically impure material was treated with synthase, and the specific radioactivities of both substrate and product were determined at different extents of the reaction. The crude results are given in Table IV. Most of the label was released in water during the reaction, but the isolated glucosamine-6P contained tritium at $\mathrm{C}_{2}$ at a calculated specific activity of about $1 \%$ of that of $(1 R)-\left[1-{ }^{3} \mathrm{H}\right]$ fructose- $6 \mathrm{P}$ (ratio $C / B_{0}$, Table IV). A more direct method was used to verify this value. The isolated glucosamine- $6 \mathrm{P}$, obviously contaminated by the $1-{ }^{3} \mathrm{H}$ isomer, was incubated overnight with glucosamine-6P deaminase: under these conditions $7.7 \%$ of the tritium was released into the lyophilized water (Table V). The residue liberated in turn $90 \%$ of the remaining counts through incubation with mannosephosphate isomerase. This experiment, summarized in Table V, demonstrated that at least $91 \%[0.9(100-7.7)+7.7]$ of the radioactivity of glucosamine- $6 \mathrm{P}$ was located at $\mathrm{C}_{1}$ and $\mathrm{C}_{2}$.

Isotope Partitioning Experiments. The appearance of solvent tritium in the remaining substrate and in the product was determined at five extents of the reaction. The values of the specific radioactivity of remaining fructose- $6 \mathrm{P}$ together with the values of the specific radioactivity of the product (both expressed as a function of the specific radioactivity of the solvent) are shown in Table VI. Within experimental error, the specific activity of the product is independent of the extent of the reaction in the range studied, $4-31 \%$. 
Table V. Determination of ${ }^{3} \mathrm{H}$ Position in Glucosamine-6P Resulting from the Intramolecular Transfer Experiment

part $A::^{a}\left[{ }^{3} \mathrm{H}\right] \mathrm{GlcNH}_{2}-6 \mathrm{P} \stackrel{\text { deaminase }}{\rightleftarrows}$

$$
(1 S)-\left[1-{ }^{3} \mathrm{H}\right] \text { Fru-6P }+ \text { Fru-6P }+{ }^{3} \mathrm{H}_{2} \mathrm{O}
$$

part $\mathrm{B}^{b}(1 S)-\left[1-{ }^{3} \mathrm{H}\right]$ Fru-6P $\stackrel{\text { PMI }}{\rightleftarrows}$ mannose- $6 \mathrm{P}+{ }^{3} \mathrm{H}_{2} \mathrm{O}$

\begin{tabular}{cccc}
\hline & enzyme added & $\begin{array}{c}\text { cpm released } \\
\text { into water }\end{array}$ & $\begin{array}{c}\text { \% of total } \\
\text { counts }\end{array}$ \\
\hline & none & 90 & 1.8 \\
Part A & deaminase & 480 & 9.5 \\
Part B & PMI & 3140 & 90 \\
\hline
\end{tabular}

a The labeled glucosamine-6P was isolated from the experiment described in Table IV. The incubation mixture containing in $0.5 \mathrm{~mL} 100$ $\mathrm{mM}$ Hepes, $\mathrm{pH} 7.3,2.4 \mathrm{mM} \mathrm{GlcNH}_{2}-6 \mathrm{P}(5040 \mathrm{cpm})$, and deaminase (2.4 units) was incubated overnight at $25^{\circ} \mathrm{C}(91 \%$ reaction). The solution was lyophilized, and water was counted. ${ }^{b} 70 \%$ of the residue left from the above experiment was incubated in $0.7 \mathrm{~mL}$ of $50 \mathrm{mM}$ Hepes, $\mathrm{pH} 7.3,1.35 \mathrm{mM}$ Fru-6P $(3500 \mathrm{cpm})$, and mannose-6P isomerase (PMI, 7 units) at $30^{\circ} \mathrm{C}$ for $5 \mathrm{~h}$. Water was then lyophilized and counted.

\section{Scheme I}
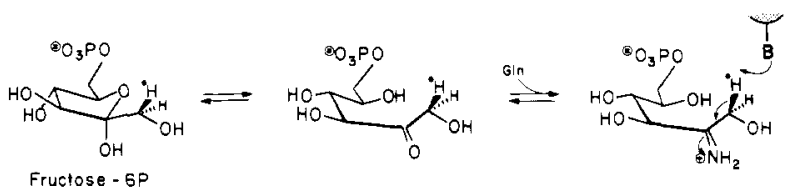

Fructose - 6P

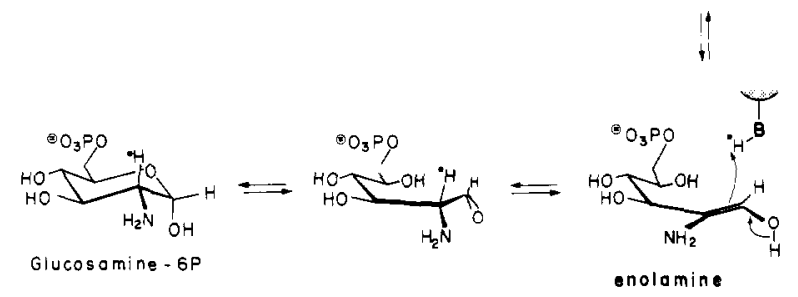

\section{Discussion}

About 3 decades ago, ${ }^{8}$ Rose proposed an attractive pathway for the ketose/aldose isomerases involving proton abstraction from either substrate to give an enzyme-bound cis-enediol intermediate. This mechanism has been verified for most isomerases and studied in detail for triosephosphate isomerase leading to the famous "TIM energetic profiles".15,16 In light of the mechanism postulated for glucosamine-6P deaminase, ${ }^{6}$ we investigated some aspects of the mechanistic pathway of the reaction catalyzed by E. coli glucosamine- $6 \mathbf{P}$ synthase.

By use of both $(1 R)-\left[1-{ }^{3} \mathrm{H}\right]-$ and $(1 S) \cdot\left[1-{ }^{3} \mathrm{H}\right]$ fructose- $6 \mathrm{P}$ as substrates, glucosamine-6P synthase was shown to catalyze the stereospecific, glutamine-requiring exchange of the pro- $R \mathrm{C}_{1}$ proton of the sugar. It would appear that the $C_{1}$ tritium is removed from the 2-imino or the 2-carbinolamine derivative though the binding of glutamine could simply activate the enzyme. It seems however likely that the real species that enolizes is the imine as shown in Scheme I. The extent on stereospecificity of labeling of glucosamine-6P by the synthase is judged from the above experiments to be $100 \%$. The stereochemistry at $C_{1}$ of the fructose- $6 \mathrm{P}$ relative to the stereochemistry at $\mathrm{C}_{2}$ of glucosamine- $6 \mathrm{P}$ follows the pattern established for a number of enzymes in the isomerase class; that is, proton removal and readdition must occur from the same face of an enolamine intermediate. Evidence for a cis-enediol $\mathrm{fc}$ 'other isomerases and for a cis-enolamine in the glucosamine-6P deaminase case has been obtained by the demonstration of intramolecular proton transfer, making an antarafacial approach less acceptable. ${ }^{8}$

In light of Table IV it is evident that the label that is transfered from $C_{1}$ of the substrate to $C_{2}$ of the product is very small. As pointed out for the TIM-catalyzed reaction, ${ }^{17}$ possible sources of

(15) Albery, W. J.; Knowles, J. R. Biochemistry 1976, 15, 5627-5631.

(16) Nickbarg, E. B.; Knowles, J. R. Biochemistry 1988, 27, 5939-5947. errors must therefore be considered very carefully. A value of ${ }^{3} \mathrm{H}$ transfer that is too low would be obtained if some ${ }^{3} \mathrm{H}$ is not bound to the initial substrate or if the synthase reaction is not irreversible. The first point is unlikely since the material used as substrate has been subjected to several ion-exchange chromatographies during the purification: all the intermediates (fructose-1,6 $\mathrm{P}_{2}$, fructose, and fructose-6P) were cleanly resolved under the conditions described under Experimental Section. As no irreversibly glucosamine-6P-processing enzyme was available, the question of irreversibility of the synthase-catalyzed reaction was checked in the present work by use of $\left[2-{ }^{3} \mathrm{H}\right]$ glucosamine-6P. A small $(2 \%)$ washout of the label (data not shown) was observed over a 5 -h incubation period. This value was estimated to be too low to seriously alter the results of experiments run under similar conditions.

A value of the percentage of ${ }^{3} \mathrm{H}$ transfer that is too high would be obtained (a) if the starting $(1 R)-\left[1{ }^{3} \mathrm{H}\right]$ fructose- $6 \mathrm{P}$ is contaminated with $\left[{ }^{3} \mathrm{H}\right]$ glucosamine-6P, (b) if there is any ${ }^{3} \mathrm{H}$ label attached at another position than $\mathrm{C}_{1}$ of the substrate, or (c) if there is any $1 S-1 \cdot{ }^{3} \mathrm{H}$ isomer present in the substrate.

The preparation of $(1 R)-\left[1-{ }^{3} \mathrm{H}\right]$ fructose-6P by glucosephosphate isomerase catalyzed isomerization of glucose- $6 \mathrm{P}$ in tritiated water precluded a priori the presence of glucosamine-6P. Moreover, the purification procedure mentioned above makes point a especially unlikely. Considering point $b$, the total amount of ${ }^{3} \mathrm{H}$ located at $C_{1}$ can be determined by adding the percentage of radioactivity released following incubation with phosphoglucose isomerase on one hand and phosphomannose isomerase on the other hand. The difference to $100 \%(100-97.3=2.7 \%$, Table III $)$ represents the highest amount of tritium located at positions other than $\mathrm{C}_{1}$.

From the result of incubations with PGI and PMI an $8 \%$ contamination of $(1 R)-\left[1-{ }^{3} \mathrm{H}\right]$ fructose- $6 \mathrm{P}$ by the $1 S-1-{ }^{3} \mathrm{H}$ isomer was calculated. The results of the intramolecular tritium transfer experiment using this substrate and presented in Table IV could not therefore be used to determine accurately the amount of intramolecular tritium transfer $C / B_{0}$, where $C$ is the specific radioactivity of $\left[2 \cdot{ }^{3} \mathrm{H}\right]$ glucosamine- $6 \mathrm{P}$ and $B_{0}$ the specific activity of starting $(1 R)-\left[1-{ }^{3} \mathrm{H}\right]$ fructose-6P. An estimated value of $1 \%$ was calculated from the determination of the specific radioactivity of recovered glucosamine-6P $\left(C_{\text {exp }}\right)$ using the relation $C=C_{\text {exp }}$ $-(a+b) B_{0 \text { exp }}$, where $B_{0 \text { exp }}$ is the specific radioactivity of the starting $\left[1-{ }^{3} \mathrm{H}\right]$ fructose- $6 \mathrm{P}, a$ the contamination by $1 S$ isomer, and $b$ the contamination at positions other than $C_{1}(a+b=0.078$ $+0.027=0.1$ ). A more direct estimation of the tritium transfer was made with glucosamine-6P deaminase which abstracts the $\mathrm{C}_{2}$ proton of glucosamine-6P and exchanges it totally with the solvent during the conversion into fructose- $6 \mathrm{P}$ and ammonia. Upon incubation of the isolated glucosamine-6P with deaminase, [2${ }^{3} \mathrm{H}$ ]glucosamine-6P totally releases its tritium in the medium whereas $\left[1-{ }^{3} \mathrm{H}\right]$ glucosamine-6P is converted into $(1 S)-\left[1-{ }^{3} \mathrm{H}\right]-$ fructose- $6 \mathrm{P}$ (Table VA); $7.7 \%$ of the counts were released into the medium. The residue of the deaminase incubation released in turn $83 \%[0.9 \times(100-7.7)]$ of the counts initially present in glucosamine-6P upon incubation with mannosephosphate isomerase (Table VB). However, as determined in Table V, the deaminase reaction did not go to completion; the equilibrium constant of $0.22 \mathrm{M}$ in favor of glucosamine- $6 \mathrm{P}^{5}$ explains that $9 \%$ of the amino sugar was still present after overnight incubation. As the deaminase totally equilibrates the proton at the $C_{2}$ position, the remaining amino sugar was present as $\left[1-{ }^{3} \mathrm{H}\right]$ glucosamine-6P; therefore, its tritium cannot be released in the medium upon treatment with phosphomannose isomerase. Taking this fact into account, we can calculate that (i) $99 \%[0.99 \times(100-7.7)+7.7]$ of the radioactivity in glucosamine- $6 \mathrm{P}$ was located at $\mathrm{C}_{1}+\mathrm{C}_{2}$, a result consistent with the analysis performed on the initial substrate fructose- $6 \mathrm{P}$, and (ii) $7.8 \%(7.7 / 0.99)$ of the tritium is located at $\mathrm{C}_{2}$.

The real tritium transfer occurring during the synthase-mediated reaction is therefore $7.8 \%$ of the experimentally determined value

(17) Herlihy, J. M.; Maister, S. G.; Albery, W. J.; Knowles, J. R. Biochemistry 1976, 15, 5601-5607. 
Table VI. ${ }^{3} \mathrm{H}_{2} \mathrm{O}$ Isotope Partition and Discrimination

$$
\text { Fru-6P } \underset{\text { synthase }}{\stackrel{{ }^{3} \mathrm{H}_{2} \mathrm{O} / \mathrm{Gln}}{\longrightarrow}} \mathrm{GlcNH}_{2}-6 \mathrm{P}
$$

\begin{tabular}{ccccc}
\hline $\begin{array}{c}\text { fractional } \\
\text { extent of } \\
\text { reaction }(\%)\end{array}$ & $\begin{array}{c}\text { sp. radioact. } \\
\text { of substrate } \\
(\mathrm{cpm} / \mu \mathrm{mol})\end{array}$ & $\begin{array}{c}\text { isotopic content } \\
\text { of substrate, } \\
s / x(\%)^{a}\end{array}$ & $\begin{array}{c}\text { sp. radioact. } \\
\text { of product } \\
(\mathrm{cpm} / \mu \mathrm{mol})\end{array}$ & $\begin{array}{c}\text { isotopic content } \\
\text { of product, } \\
p / x(\%)^{b}\end{array}$ \\
\hline $3.8^{c}$ & 1300 & 0.6 & 230110 & 1.06 \\
$6.9^{c}$ & 1475 & 0.7 & 244180 & 1.13 \\
$9.1^{c}$ & 1920 & 0.9 & 235810 & 1.09 \\
$21.2^{d}$ & 3925 & 1.5 & 250600 & 0.96 \\
$31.1^{d}$ & 4685 & 1.8 & 229230 & 0.88 \\
\hline
\end{tabular}

${ }^{a}$ Isotopic content of the substrate represents the ratio of the specific radioactivity of Fru-6P $(s)$ to that of the solvent $(x),{ }^{b}$ Isotopic content of the product represents the ratio of the specific radioactivity of $\mathrm{GlcNH}_{2}-6 \mathrm{P}(p)$ to the specific radioactivity of the solvent $(x)$. ${ }^{c}$ The reaction mixture at $25^{\circ} \mathrm{C}$ contained in $3 \mathrm{~mL}$ of tritiated water $\left(216700 \mathrm{cpm} / \mu \mathrm{mol}\right.$ of $\left.\mathrm{H}^{+}, x\right)$ Fru-6P $(20 \mathrm{mM})$, glutamine $(20 \mathrm{mM})$, Hepes $(50 \mathrm{mM})$, pH 7.3 , and glucosamine- $6 \mathrm{P}$ synthase $(0.72$ units). $0.75-\mathrm{mL}$ aliquots were removed at 10,20 , and $30 \mathrm{~min}$ and acidified to $\mathrm{pH} 2 \mathrm{with} 2 \mathrm{~N} \mathrm{HCl}(0.1 \mathrm{~mL})$. After the $\mathrm{pH}$ was raised to $7-8$ with $10 \mathrm{~N} \mathrm{NaOH}(8 \mu \mathrm{L})$, Fru-6P and $\mathrm{GlCNH}_{2}-6 \mathrm{P}$ were quantified by the anthrone and Morgan-Elson procedures. For each sample water was lyophilized, and Fru-6 $\mathrm{P}$ and $\mathrm{GlcNH}_{2}-6 \mathrm{P}$ were purified as described under Experimental Section. ${ }^{d}$ Conditions as in footnote $a$ except for the enzyme $(2.4$ units $/ \mathrm{mL})$ and water $\left(260630 \mathrm{cpm} / \mu \mathrm{mol}\right.$ of $\left.\mathrm{H}^{+}\right)$. Incubations were stopped after 10 or $20 \mathrm{~min}$.

\section{Scheme II}
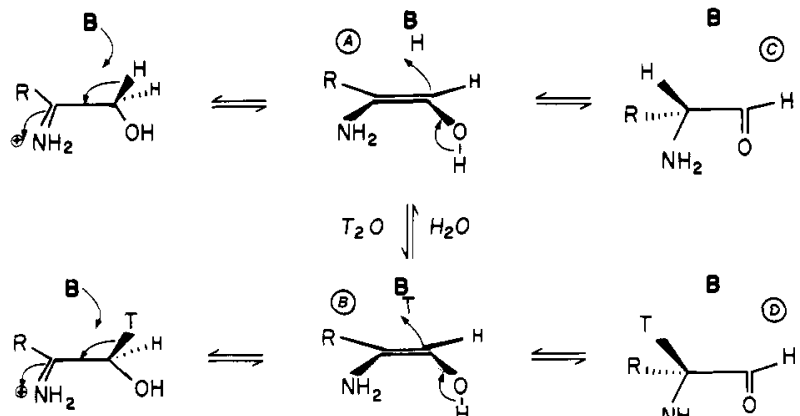
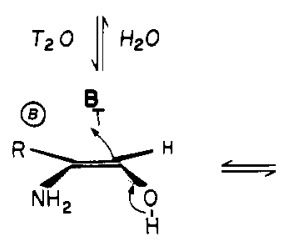

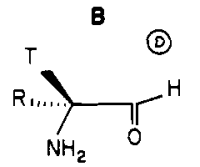

$\left(C_{\exp } / B_{0, \exp }\right.$, Table IV), that is, $0.078 \times 10.8=0.8 \%$. The ${ }^{3} \mathrm{H}$ initially present at the $1 R$ position of fructose- $6 \mathrm{P}$ was almost totally released into water, and most of the counts present in the isolated product were derived from the $1 S$ labeled substrate, explaining the high amount of tritium transfer determined experimentally $\left(C_{\exp } / B_{0, \exp }\right.$, Table IV).

Since in the absence of synthase neither fructose-6P nor glucosamine-6P exchanges protons from $\mathrm{C}_{1}$ or $\mathrm{C}_{2}$ with the solvent to a significant degree, the enzymatic reaction must proceed via a reaction intermediate that is in rapid protonic exchange with the medium. The obvious candidate for such a species is the enzyme-bound cis-enolamine indicated in Scheme II in which the protonated (A) and tritiated (B) forms must be in rapid equilibrium.

The amount of tritium left in the remaining substrate depends upon both the primary isotope effect, which tends to increase its specific radioactivity, and the partitioning ratio of the enolamine intermediate on which depends the rate at which the tritium is washed out of the substrate; from Table IV we calculated that the specific radioactivity of the substrate $(B)$ is about 3 times lower near the end of the reaction than at the beginning, showing that the primary isotope effect is not preponderant in the process. The contamination of $\left[1-{ }^{3} \mathrm{H}\right]$ fructose- $6 \mathrm{P}$ by the $1 S$ isomer did not allow observation of a parallel decrease of the specific radioactivity of the product. Comparison of the relative rates of conversion and tritium release shows that deprotonation of fructose- $6 \mathrm{P}$ must be faster than conversion into glucosamine-6P.

The existence of an enzyme-bound intermediate in protonic exchange with the solvent (Scheme II) makes it possible to feed ${ }^{3} \mathrm{H}$ from the tritiated water into the remaining substrate and into the product. Since A and B are at equilibrium, the relative rate of $\mathrm{A}$ to give unlabeled product (via $\mathrm{C}$ ) and of $\mathrm{B}$ to give labeled product (via D) is measured in this isotopic discrimination in the formation of glucosamine-6P.

Second, since only the intermediate exchanges rapidly with the solvent (via $\mathrm{A} \rightleftarrows \mathrm{B}$ ), the partitioning of the intermediate between breakdown back to substrate and reaction forward to give product can be observed. As shown in Table VI, the specific radioactivity

of the product is very close to that of the solvent in which the reaction is run; that is, discrimination against tritium is close to 1. This value, much smaller than expected values for the primary tritium isotope effects $(6-20),{ }^{18}$ suggests that the proton transfer step in which the intermediate (A and B) collapses to form glucosamine-6P is followed by a slower step. We can conclude therefore that, in this experiment, the step following protonation at $\mathrm{C}_{2}$ is rate limiting. This step involves most likely the release of one product (glutamate, glucosamine-6P, or both).

The appearance of tritium in the remaining substrate (Table VI) indicates a high forward commitment since the intermediate collapses to form product much faster that it partitions back to the substrate. The plot of percent exchange into fructose versus conversion indicates (from the slope, data not shown) that the enolamine intermediate reacts forward to give glucosamine-6P (conversion) 23 times faster than it falls back to yield tritiated fructose-6P (exchange). As we stopped the reaction at early stages, we could not see the upward curvature of the exchange/conversion plot which should occur as the reaction proceeds. The low tritium incorporation in substrate suggests that isotopic exchange at the enolamine is preceded by a rate-limiting step. This step could either be the formation of fructosimine- $6 \mathrm{P}$ or the deprotonation of this intermediate. The results of intramolecular tritium transfer (Table $\mathrm{V}$ ) showed that the tritium release from labeled fructose-6P is faster than conversion, suggesting that proton abstraction is faster than conversion into product. The formation of the postulated fructosimine-6P (Scheme I) would therefore represent the slowest step of the reaction.

So far the primary deuterium isotope effect using $(1 R)$-[1$\left.{ }^{2} \mathrm{H}\right]$ fructose-6P has not been investigated. We do not expect however to see any isotope effect since the release of the label into solvent would occur faster than conversion into product.

\section{Conclusions}

Although the present study has encountered difficulties due to (1) the impossibility of studying the reverse reaction and (2) the contamination of $(1 R)-\left[1-{ }^{3} \mathrm{H}\right]$ fructose- $6 \mathrm{P}$ by the $1 S-1-{ }^{3} \mathrm{H}$ isomer (which could have been overcome by using mannosephosphate isomerase and more easily solved through double isotope labeling), we can draw the following conclusions for the glucosamine-6P synthase catalyzed reaction.

Given the stereospecificity of $C_{1}$ proton abstraction and the existence of a low intramolecular tritium transfer, the mechanism of this $2 R$ ketose/aldose isomerase is modeled on the scheme proposed for the reversible glucosamine- $6 \mathrm{P}$ deaminase. ${ }^{6}$ Following the stereospecific proton abstraction on the fructosimine-6P, the cis-enolamine would be protonated on the $R e$ face at $\mathrm{C}_{2}$.

From the intramolecular transfer experiment, the deprotonation step has been shown to be faster than conversion; that is, the energetic barrier of step 4 (Scheme III) is higher compared to

(18) Bell, R. P. The Proton in Chemistry; Cornell University Press: New York, 1973 
Scheme III

$$
\begin{gathered}
E \cdot F r u-6 P=E \cdot F r u-6 P-G i n \stackrel{1}{=} E \cdot F r u=N_{2}^{+} \\
E+G I c H_{2}-6 P \stackrel{4}{=} E \cdot G l c N H_{2}-6 P
\end{gathered}
$$

that of step 2. The product of the synthase-catalyzed reaction in tritiated water contains $1 \mathrm{~mol}$ of tritium $/ \mathrm{mol}$. That is, enolamine shows no discrimination between ${ }^{1} \mathrm{H}$ and ${ }^{3} \mathrm{H}$ when picking up hydrogen at $\mathrm{C}_{2}$ : this can be interpreted as a minimum for energetic barrier 3 . The exchange/conversion experiment in tritiated water has shown that the intermediate collapses to tritiated product 23 times as often as it collapses to tritiated substrate. The very low tritium incorporation into fructose- $6 \mathrm{P}$ requires the exchange to be posterior to a slow step; as step 2 is lower in energy than step 4 , step 1 must be rate limiting. Therefore, the ratio $23 / 1$ reflects the rate difference between steps 1 and 4 ; that is, barrier 1 is about $1.9 \mathrm{kcal} / \mathrm{mol}$ higher than barrier 4 .

The precedent results raise the question about the nature of the irreversible step of the reaction. We recently demonstrated that the enzyme obeys a $\mathrm{BiBi}$ ordered mechanism with fructose- $6 \mathrm{P}$ binding first and glucosamine-6P leaving last. For imine formation, the enzyme must therefore bind fructose-6P and then glutamine. Glutamate could then be released at step 1 (Scheme III); in this case the low tritium incorporation in the substrate, when the reaction is run in tritiated water, could result in imine hydrolysis into fructose- $6 \mathrm{P}$ and ammonia, making this step virtually irreversible. Alternatively, the release of glutamate could occur at step 4 just before the release of glucosamine-6P. Whatever the position of glutamate release in this mechanism is, the energetic barrier of step 4 involves most likely an important conformational change. Although such a behavior has not been yet detected during catalysis, it is known to occur with glutamine site directed irreversible inhibitors as exemplified by half of the sites reactivity of glucosamine-6P synthase with the affinity label 6-diazo-5-oxo-L-norleucine. ${ }^{9}$

Acknowledgment. We thank Dr. Rousseau (CEA, Saclay, France) for his hospitality and Dr. A. M. Moustier for running the tritiation experiment in the synthesis of $(1 R)-\left[1-{ }^{3} \mathrm{H}\right]$ fructose- $6 \mathrm{P}$ used in the determination of intramolecular hydrogen transfer. Financial support from Ligue Nationale Française Contre Pe Cancer to one of us (B.G.-P.) is gratefully acknowledged.

\title{
Schiff Bases and Geminal Diamines Derived from Pyridoxal 5'-Phosphate and Diamines
}

\author{
Pierre-Marie Robitaille, R. David Scott, Junying Wang, and David E. Metzler* \\ Contribution from the Department of Biochemistry and Biophysics, Iowa State University, Ames, \\ Iowa 50011. Received July 6, 1988
}

\begin{abstract}
The reactions of the diamines 1,2-diaminoethane, 1,3-diaminopropane, and 1,4-diaminobutane with pyridoxal 5 -phosphate to form Schiff bases and cyclic geminal diamines have been investigated by ultraviolet-visible and ${ }^{1} \mathrm{H}$ NMR spectroscopy. The formation constants, $\mathrm{p} K_{\mathrm{a}}$ values, and spectra of individual ionic species have been evaluated from the $\mathrm{pH}$ and concentration dependence of the spectra, and the formation constants have been evaluated independently from quantitative NMR data. The well-known system alanine:pyridoxal phosphate has been evaluated by the same techniques for purposes of comparison. Resolution of the absorption spectra into components by use of log normal distribution curves together with chemical shift values has permitted evaluation of cyclization constants for two different states of protonation of the Schiff bases of the diamines and also of tautomerization constants. Cyclization occurs readily for the diaminopropane system above $\mathrm{pH} 8$ but not as readily for the diaminoethane system. For the latter, tautomerization of the ketoenamine form of the Schiff base to an enolimine form occurs to a major extent in the $\mathrm{pH}$ region $6-9$. It is proposed that in this same $\mathrm{pH}$ region $\sim 13 \%$ of the 1:1 complex may be a carbinolamine species. The data are discussed in terms of the mechanism of transimination in enzymic catalysis.
\end{abstract}

There are two important reasons for studying the interaction of the coenzyme pyridoxal 5'-phosphate (PLP) with diamines. The first is to learn what interactions might be expected with diamines and higher polyamines within cells where concentrations of the polyamines spermidine and spermine may reach $1 \mathrm{mM}^{1}$ and that of PLP nearly $0.1 \mathrm{mM}^{2}$ Such interactions may be important both in the regulation of PLP levels and in the metabolism of these polyamines and of 1,4-diaminobutane (putrescine). The isolation of a reduced Schiff base of PLP with spermidine from sodium borohydride treated urine ${ }^{3}$ suggests that formation of Schiff bases or geminal diamines from PLP and polyamines may occur in body fluids. It has been suggested that this interaction within the urine may be a cause of depletion of tissue PLP during pregnancy and

(1) Lotfield, R. B.; Eigner, E. A.; Pastuszyn, A. In Polyamines in Biology and Medicine; Morris, D. R., Marton, L. J., Eds.; Marcel Dekker: New York 1981; pp 207-221

(2) Lumeng, L.; Li, T.-K. In Vitamin $B_{6}:$ Metabolism and Role in Growth

Tryfiates, G. P. Ed.; Food \& Nutrition Press: Westport, CT, 1980; pp 27-51.

(3) Aigner-Held, R.; Campbell, R. A.; Daves, G. D., Jr. Proc. Natl. Acad. Sci. U.S.A. 1979, 76, 6652-6655. in some pathological conditions. ${ }^{4}$

The second reason for studying these interaction is that geminal diamines are presumed intermediates in most PLP-dependent enzymatic reactions. Study of geminal diamines formed from 1,2-diaminoethane (ethylenediamine), 1,3-diaminopropane, and 1,4-diaminobutane may shed light on these processes. Previous investigations have dealt with the reactions of salicylaldehyde, ${ }^{5,6}$ 5-deoxypyridoxal, ${ }^{6}$ and PLP $^{7,8}$ with diaminoethane and diaminopropane. Kenniston ${ }^{9}$ measured formation constants of Schiff bases of PLP at pH 7.4 for a large series of diamines. Despite this abundance of literature, there is disagreement in interpretation

(4) Campbell, R. A. In Polyamines in Biology and Medicine; Morris, D R., Marton, L. J., Eds.; Marcel Dekker: New York, 1981; pp 401-405. (5) McQuate, R. S.; Leussing, D. L. J. Am. Chem. Soc. 1975, 97, $5117-5125$.

(6) Metzler, C. M.; Cahill, A.; Metzler, D. E. J. Am. Chem. Soc. 1980. $102,6075-6082$.

(7) Tobias, P. S.: Kallen, R. G. J. Am. Chem. Soc. 1975, 97, 6530-6539.

(8) O'Leary, M. H. Biochim. Biophys. Acta 1971, 242, 484-492.

(9) Kenniston, R. C. Physiol. Chem. Phys. 1979, 11, 465-470. 